\title{
RESEARCH AND DEVElopMent OF AN ARTIFICIAl NeURAl Network FOR SPECTRAL DATA
}

\author{
Theo Dedeken \\ Ghent University, Faculty of Sciences, Krijgslaan 281, 9000 Ghent, Belgium \\ e-mail: theo.dedeken@telenet.be
}

\begin{abstract}
There is a global call to determine the state of the inventory of transport and storage containers for high radioactive waste (spent fuel assemblies). One possible solution is to perform vibration analyses and evaluate vibration responses by using artificial neural networks. For this approach, first investigations have been carried out. Vibration data are obtained from a testing setup modelling the nuclear storage fuel assemblies which is converted to the frequency domain via the Fourier transform. Raw spectral data are first prepared by normalization, data augmentation and limiting the frequency range. These measures are proven to have significant impact on the overall performance of the training of the neural networks. Using fully connected and convolutional neural networks, classification and regression is performed on the spectral data. Classification is shown to be possible with very high accuracy; and regression has decent results with options for improvement in later stages. Convolutional neural networks are shown to be superior in both cases.
\end{abstract}

\section{Keywords}

Neural networks; Spectral data; Nuclear waste monitoring; Vibration analysis.

\section{Introduction}

The storage of nuclear waste is a complex and worldwide problem. Currently there are little to none long term solutions available for storing spent fuel assemblies, hence the waste is stored in intermediate transport and storage containers inside the nuclear power plants. These storage containers require active maintaining and monitoring to avoid dangerous and environmentally damaging situations.

To research and develop novel solutions to these problems, a cooperative project was set up between Dresden Technical University (TUD) and Zittau/Görlitz University of Applied Sciences (HSZG). In light of this project different possible non-invasive measurement principles were proposed [1]. This paper focuses on the monitoring of containers using vibration analysis and training neural networks on the obtained spectral data to perform classification and assessment of the current state of the storage container inventory.

\section{$1 \quad$ Research Objectives}

The aim of the research is to develop novel machine learning solutions for the monitoring of nuclear waste containers. Specifically, by analyzing the vibrations and the resulting spectral decomposition of these signals. To achieve this, a number of neural networks were constructed and trained on the spectral data to predict the state of the waste containers. Additionally, a data augmentation workflow was built and evaluated to increase the effectiveness of the limited amount of data available. 


\subsection{Data Acquisition}

To train a neural network, first a sufficient amount of data needs to be collected. To acquire the data necessary for further research, a testing setup was developed and measurements were performed.

Scale models representing the actual fuel assemblies contained in the storage containers were constructed. The model is assembled as a collection of 16 tubes arranged in a four by four pattern. It is possible to change the amount of filament in these tubes. In this way, a number of different states were constructed; each with a different configuration.

Two main rounds of experiments were performed: the first round with five different states ranging from full to empty. In Fig 1, the configured states for this round are shown. Later, the amount of states was increased to a total of 15. The results presented in section 3 use the data obtained from the last set of experiments.
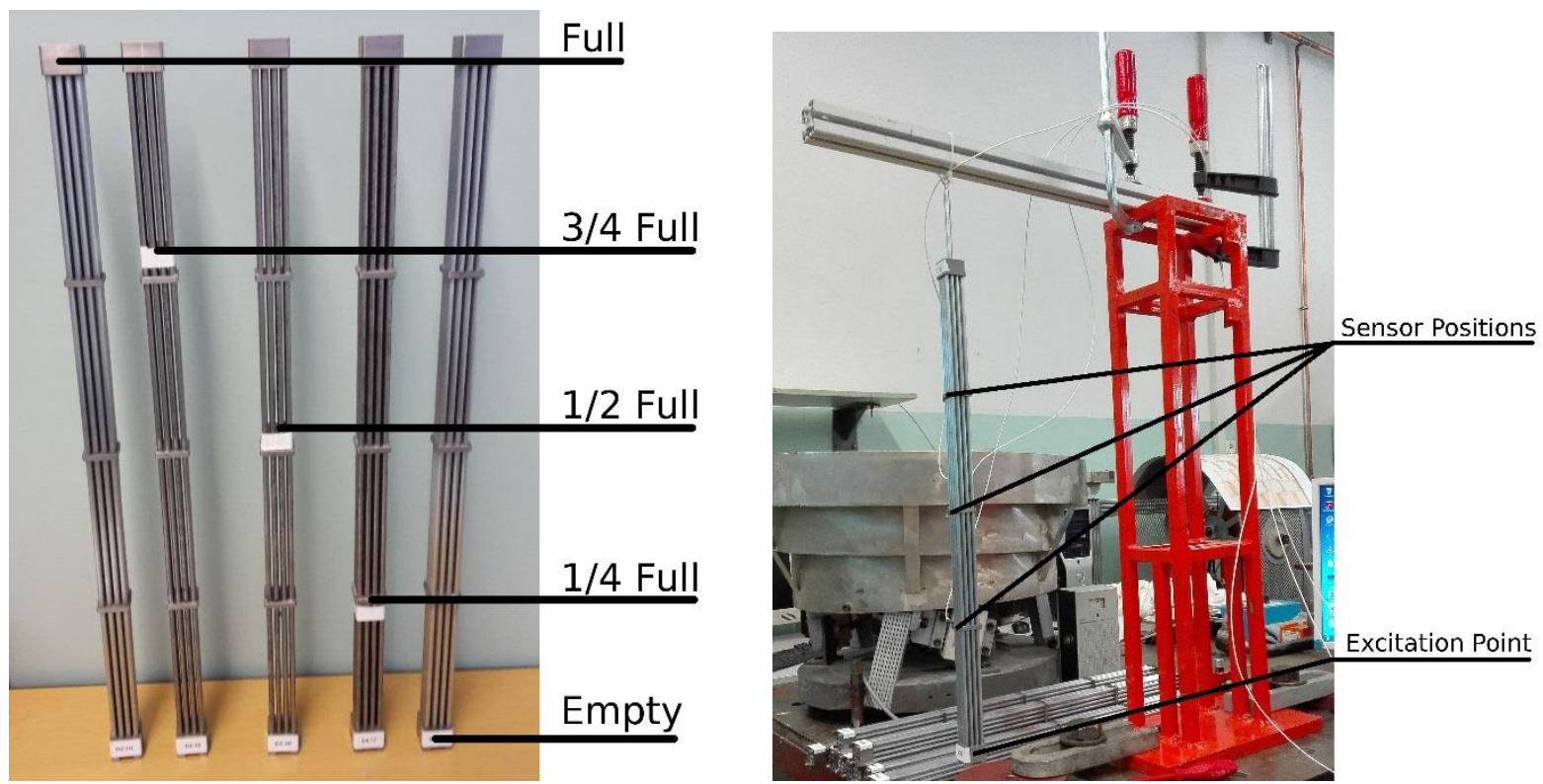

Source: Own

Fig. 1: The prepared states for the first round of experiments

To measure the vibrations on the fuel assembly models, a testing rig was set up where the model could be suspended in the air; this setup is presented in Fig 1. At three positions on the model sensors were attached to register the velocity of that position over time. The three sensors are positioned along the same axis where the impact is occurring. To perform the measurement, an impact hammer was used to hit the assembly. The resulting vibrations were then registered and normalized according to the vibrations measured on the hammer. This process was repeated ten times for each state.

\subsection{Data Preparation}

The raw data acquired from the sensors are not in a format that is useful for analysis and classification using neural networks. To capture the unique properties of each signal better, we decompose the time series in the frequency domain using the Fourier transform. This leaves us with the frequency values in between $0 \mathrm{~Hz}$ and $2000 \mathrm{~Hz}$ (Fig 2). 

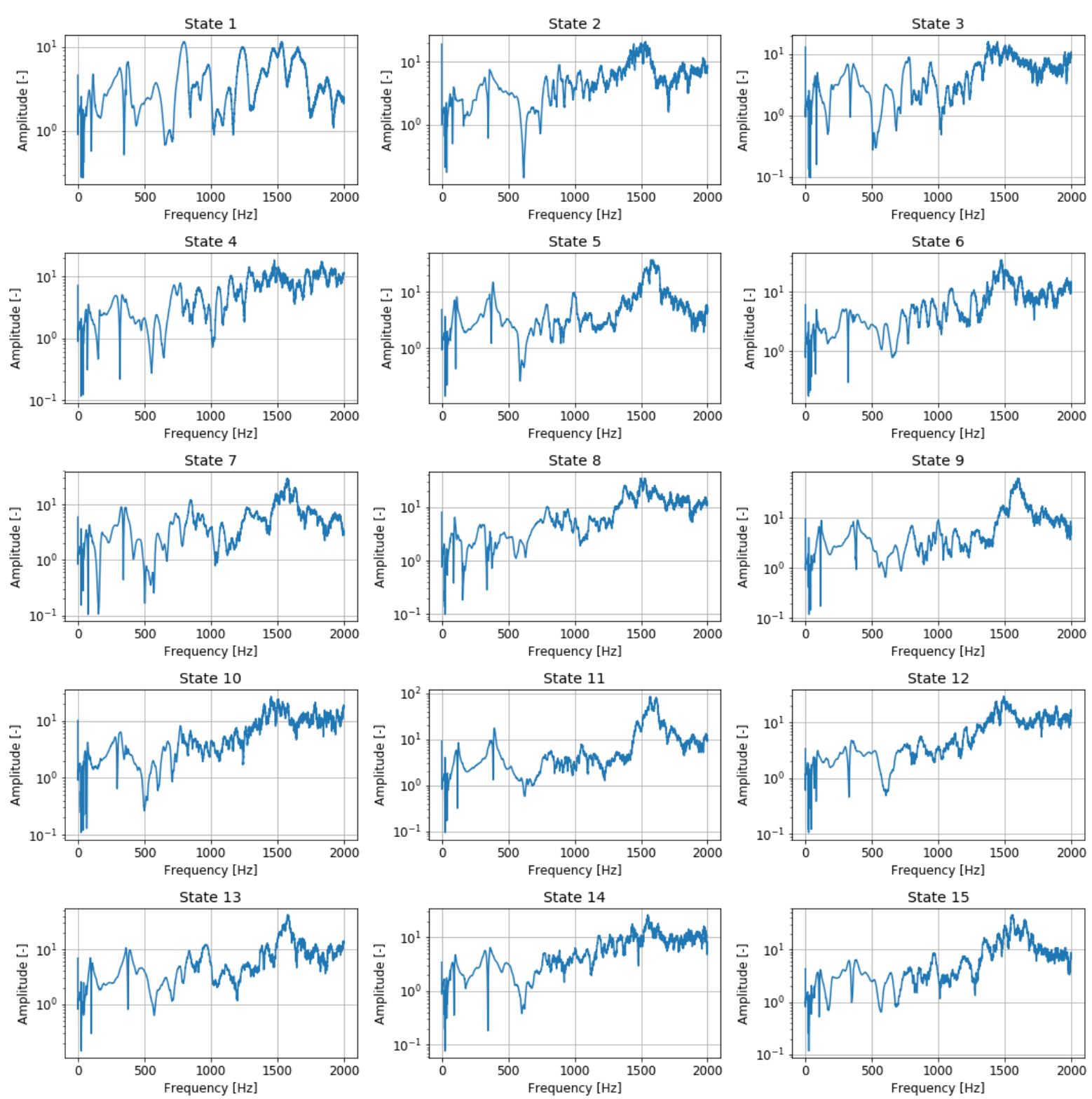

Source: Own

Fig. 2: All obtained frequency domains for the second round of experiments

\subsubsection{Removing Noise}

When looking closer at the variance of the calculated amplitude of each frequency over measurements of the same state (Fig 3), it becomes clear that there are two zones in the spectrum with variance of different magnitude. The calculated amplitudes of the frequencies ranging from $0 \mathrm{~Hz}$ to $700 \mathrm{~Hz}$ are highly similar in over multiple measurements of the same state. The higher frequencies are exceptionally dissimilar over measurements of the same state. This increase in variance can be mainly attributed to noise caused both by measurement inaccuracies and outside factors.

When training a neural network on samples which are very different but still map to the same output, we run into problems where the network has difficulties to converge to a state that can handle each case of input. Keeping in mind the construction of the spectral domain, we can assume that most of the original vibration data are defined by the values of the lower frequencies. To help the training performance of the used models, we limit the frequency range to the interval $[0 \mathrm{~Hz}, 800 \mathrm{~Hz}]$. 


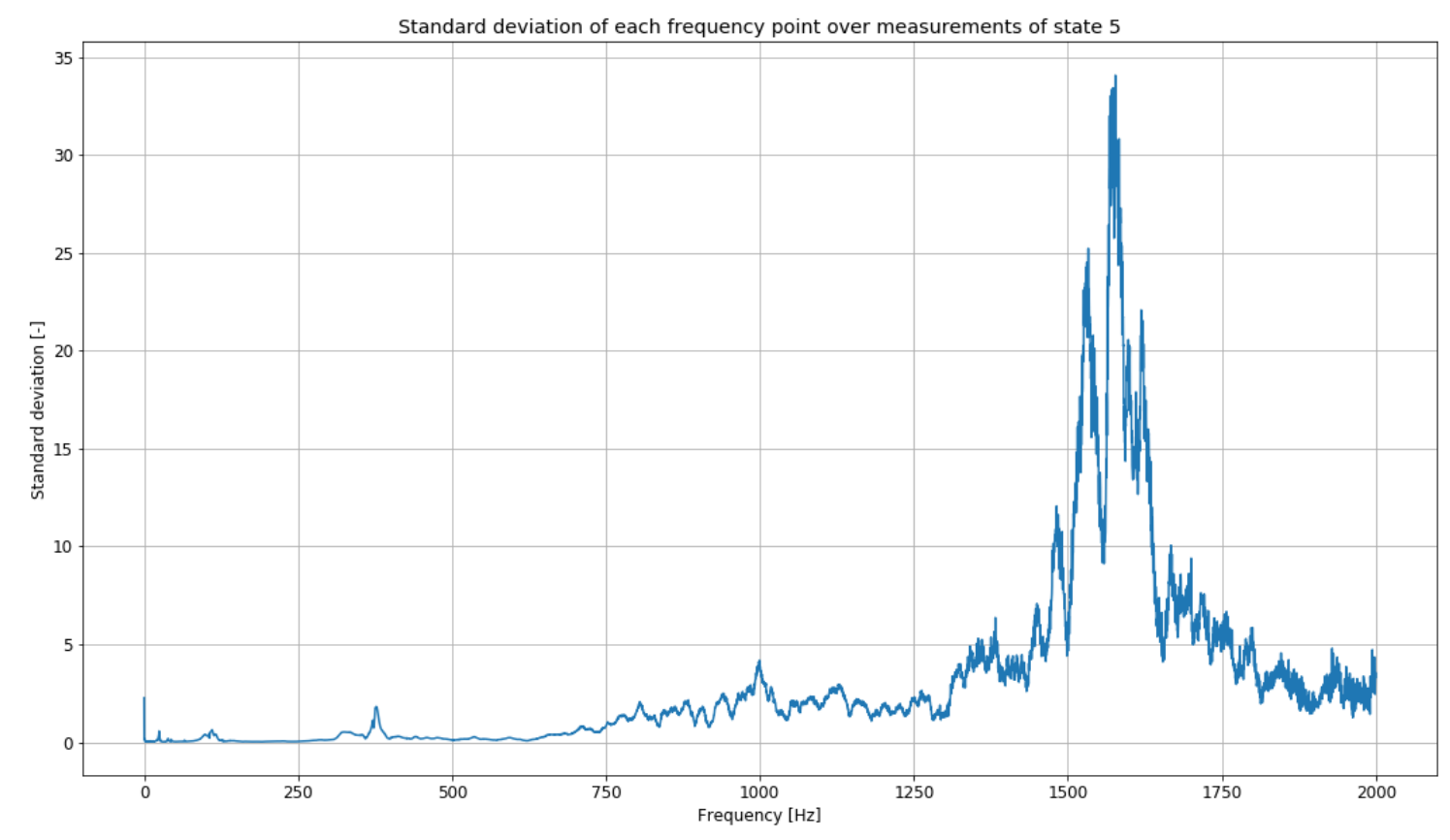

Source: Own

Fig. 3: Variance of the amplitude for each frequency over measurements of the same state

\subsubsection{Data Normalization}

Another technique used to improve training performance of the neural networks was to normalize the input data. This was achieved by subtracting the mean value of the spectrum to each value and dividing by the standard deviation afterwards to obtain a data sample with mean zero and standard deviation of one.

\subsubsection{Data Augmentation Techniques}

Since there were only ten measurements for each state, the amount of the data to train the neural networks on was very limited. To improve the performance and robustness of the network, data augmentation inspired by previous work in [2] were added. The techniques employed in this case were adding an offset to the original spectrum and multiplication of the spectrum. Offset was varied over \pm 0.1 times the standard deviation of the original sample and multiplication was varied over $1 \pm 0.1$ times the standard deviation. For each sample, nine extra samples were constructed: three using the offset technique, three using multiplication and three using the combination. This effectively increased the size of our dataset with a factor of ten. It is important to note that the augmentation was executed after the normalization of the data, otherwise the normalization operation would have converted the extra samples back to the original sample.

\subsection{Used Models}

Training was performed on the two most used variants of feed-forward neural networks, the standard fully connected and convolutional neural networks. An architecture of comparable complexity for each one of the variants was constructed and trained on the prepared spectral data. See section 3.1 for the comparison of different models.

The networks were constructed in the Keras [3] framework using the Tensorflow [4] backend. As for the optimizer, an instance of the Adam optimizer was used, configured with a learning rate of 0.0001 . 


\subsubsection{Fully Connected Neural Network}

The fully connected network shown in Fig 4 consists of an input layer, two hidden layers and the output layer. The hidden layers have 256 neurons and are combined with the Exponential Linear Unit (ELU) activation function and a dropout measure dropping out $25 \%$ of the inputs.

The depth of the neural network was kept small as increases in layers did not cause any major improvements in performance of the network. The ELU activation function has good training performance as it does not have the same problems with vanishing gradient compared to the sigmoid activation function. Dropout is added as a measure to make the resulting network more robust and prevent overfitting of the data.

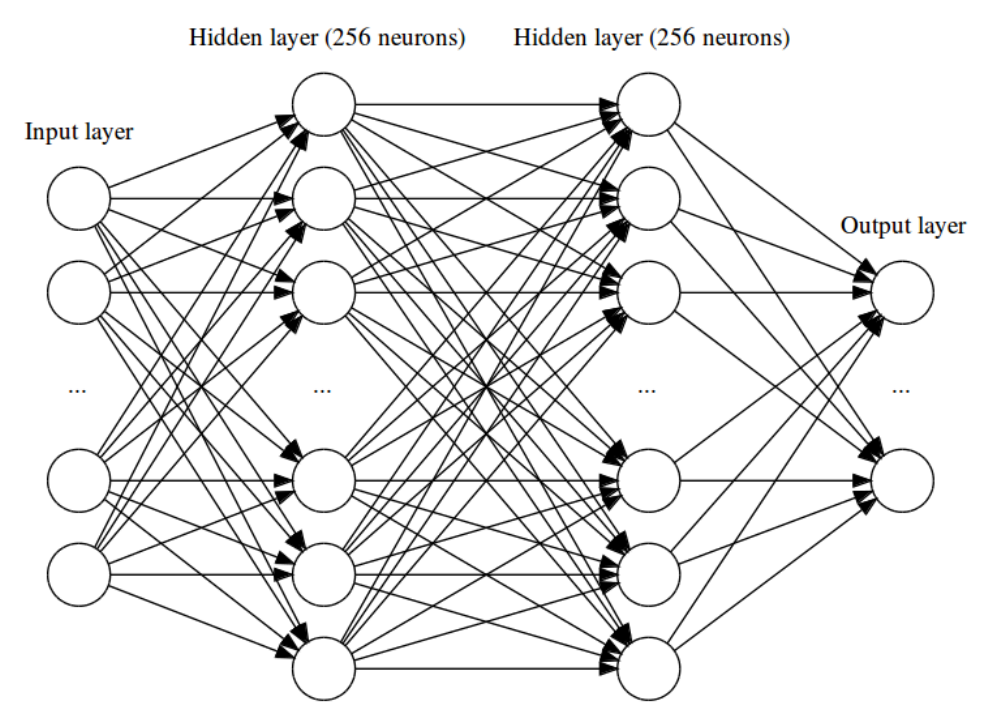

Source: Own

Fig. 4: Fully connected neural network architecture

\subsubsection{Convolutional Neural Network}

The convolutional neural network shown in Fig 5 consists of an input layer, three convolutional layers, one hidden layer and the output layer. The three convolutional layers have 32, 64 and 128 kernels respectively. After each of the convolutional layers, a max pooling operation is performed with pool size of three. At the end of these layers the input space is reduced sufficiently to be fully connected to a single hidden layer with ELU activation and a dropout measure with a dropout rate of $25 \%$.

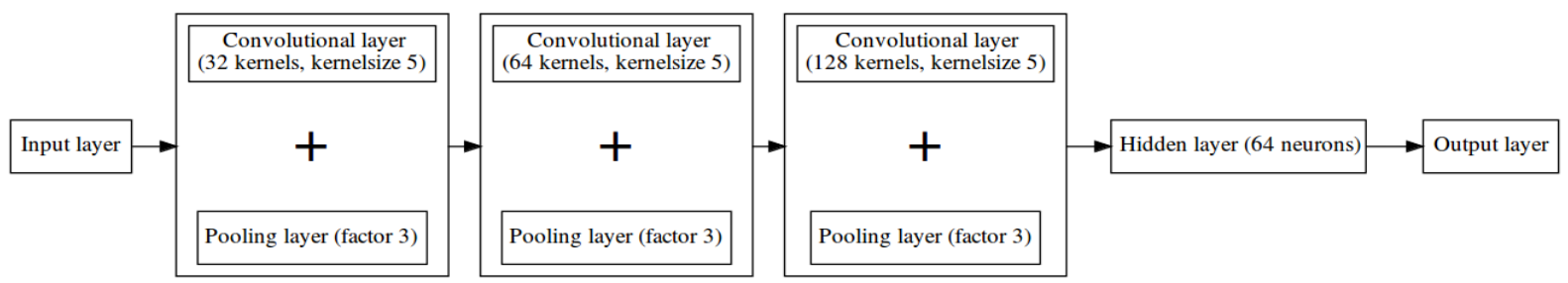

Source: Own

Fig. 5: Convolutional neural network architecture

\section{$2.4 \quad$ Training Input}

In the case of the fully connected network, the input of the network is constructed by concatenating the spectra after data preparation of the three positions. Each amplitude value in the resulting array then serves as an input node to the neural network. 
As far as the convolutional neural network is concerned, a different approach can be used. Since convolutional neural networks work on volumes rather than single input nodes, we can construct the input as a two dimensional array by stacking the spectra of each position. This resembles the way convolutional neural networks are used in the case of colour images where each image pixel has three components, one for each of the colour channels.

To make sure the model was generalizing well, a validation split of 0.5 was chosen. This meant that only half of the samples were used in the training of the network. With the addition of data augmentation, the models still had sufficient data to be trained on.

\subsection{Output Encoding}

Two different types of encoding were used for the expected output for the networks, each of them more appropriate in different approaches of solving this problem.

\subsubsection{One-Hot Encoding}

To convert the state number to this encoding, an $n$-dimensional vector was constructed ( $n$ being the number of states: 5 or 15). In this vector, all elements are zero except for the element at the position of the state being encoded.

This encoding was used to train the networks to perform a classification of the input sample. A property of this encoding is that we can interpret the output as a distribution of how confident the network is about its prediction: the more confident, the more the input will resemble the one-hot encoding. If multiple positions in the output are high, we can presume that the network recognizes properties from both states in the input. To get the output in the desired format, a softmax activation layer was added as the last layer of the models. With this output format, the categorical cross entropy between the expected output and the actual output was used as the loss measure while training.

\subsubsection{Continuous Value}

Another way to encode the state of a particular sample is to use a single value. In this case, the state number is converted to a number in the range $[0,1]$. This is done by linearly interpolating the states number to the new range.

This encoding was used when solving this problem as a regression one. As the states are numbered 1-15 going from empty to full, we can interpret the output as a value representing the amount of filling in the assembly. To limit the range of the output of the neural network model, a sigmoid activation layer was added as the last layer of the model. With this output format, the mean squared error between the expected output and the actual output was used as the loss measure while training.

\section{$3 \quad$ Results}

\subsection{Comparison of Used Models}

\subsubsection{Classification}

The evolution of the accuracy and loss function during training for each of the models is presented in Fig 6. It is clear that the convolutional model achieves the best performance in both categories. However, it is important to note that the training of the convolutional generally requires double the time per training iteration in comparison to the fully connected model. A possible explanation for this result is that the convolution kernels are able to extract 
features from the input like slopes, peaks and valleys, while a fully connected model is less likely to detect these local dependencies between values.
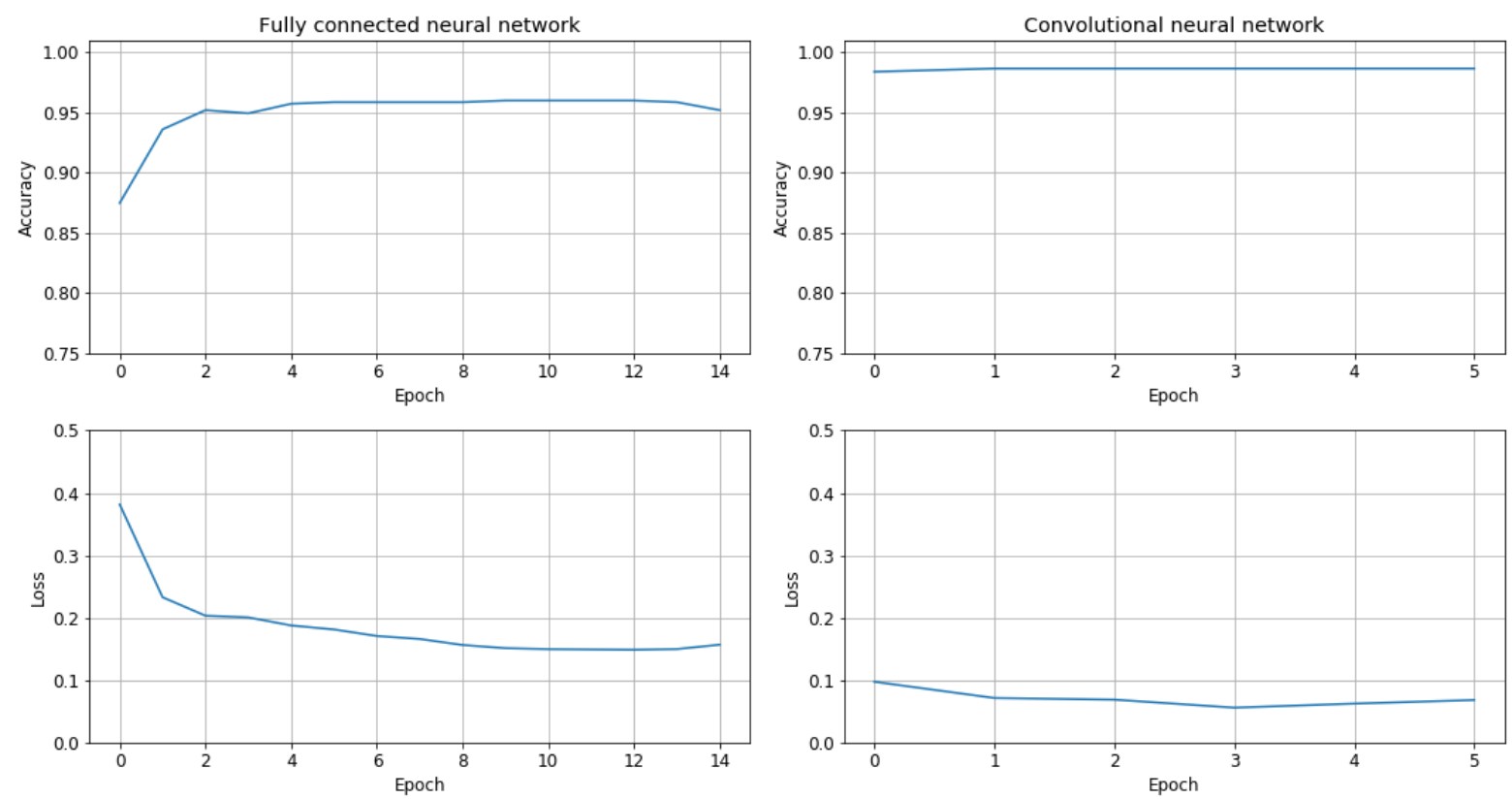

Source: Own

Fig. 6: Accuracy and loss metric for the two models

A visual representation of the accuracy of the predictions of both networks is given in Fig 7 . As both networks have high accuracy, most points match with the expected values. It can be seen that the convolutional network only wrongly classifies one sample of the testing set, while the fully connected network has worse performance.

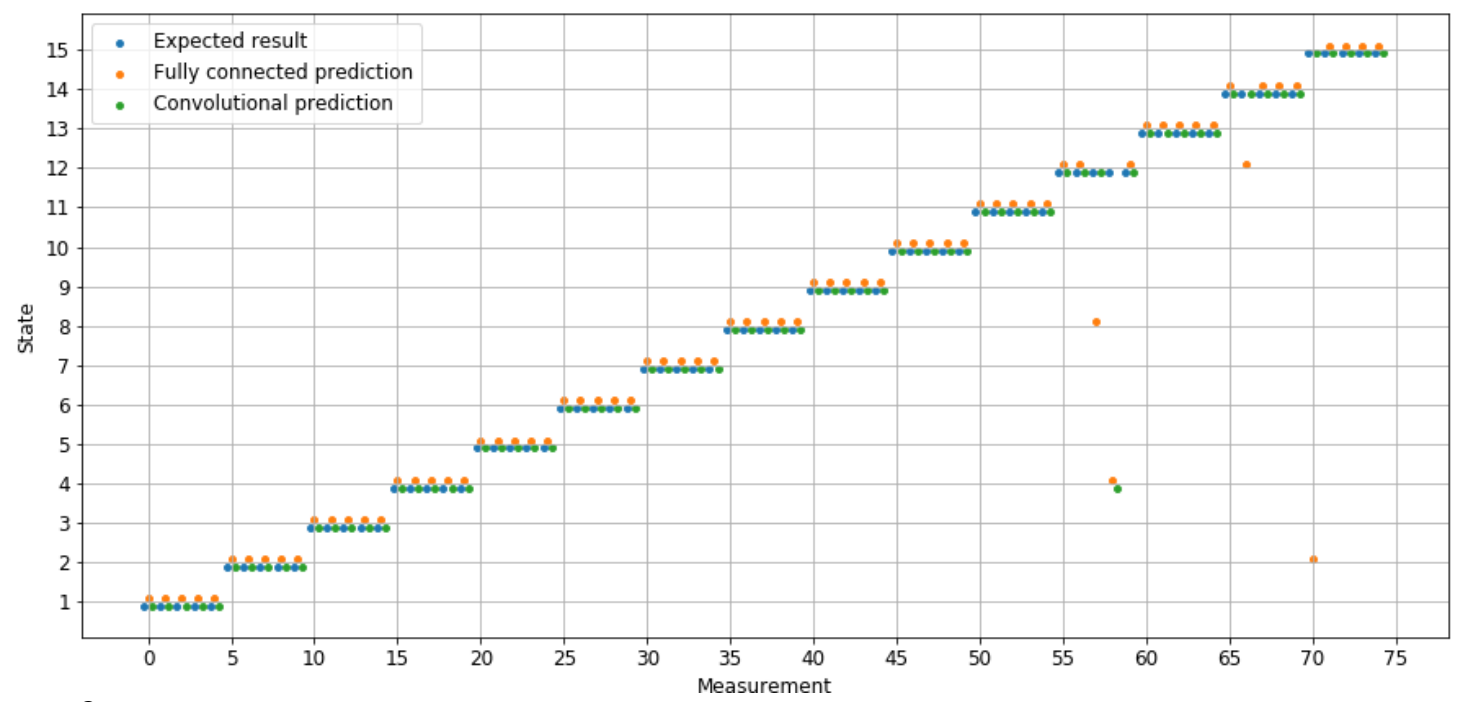

Source: Own

Fig. 7: Predictions of the different models for the samples in the test set

Another interesting observation is that the wrong predictions are not close to the actual result. This could indicate that subsequent states do not show a straightforward evolution, meaning that states are highly unique and not closely related. This could prove to be a problem when deploying these models in real world environments as the states in that case would lie in 
between the learned states and the drastic changes in spectral data might provoke erroneous predictions.

\subsubsection{Regression}

The performance of the test set for both models is presented in Fig 8 and Fig 9. Graph in Fig. 8 shows the scatter plot mapping the expected value to the predicted value. Graph in Fig 9 draws the boxplot of the predicted values for each one of the states.

In the case of regression, there is almost no performance difference between the fully connected and the convolutional neural network. Both networks achieve similar results in terms of mean squared error. The results currently obtained do not seem useful in practical application. However, an estimation from a regression network could be used in conjunction with other metrics to provide a more accurate assessment of the state of the container.
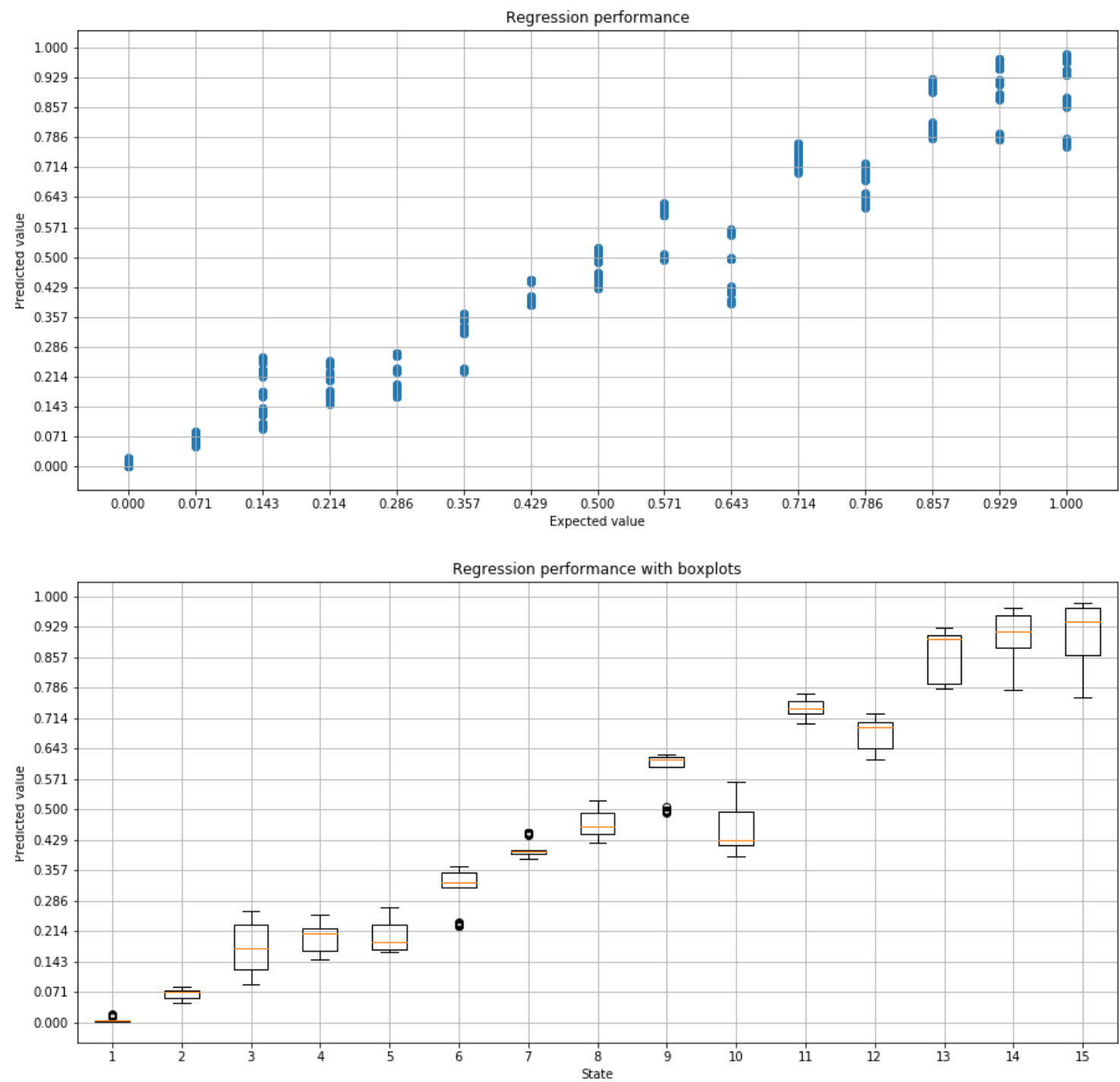

Source: Own

Fig. 8: Regression performance of the test set for the fully connected neural network 

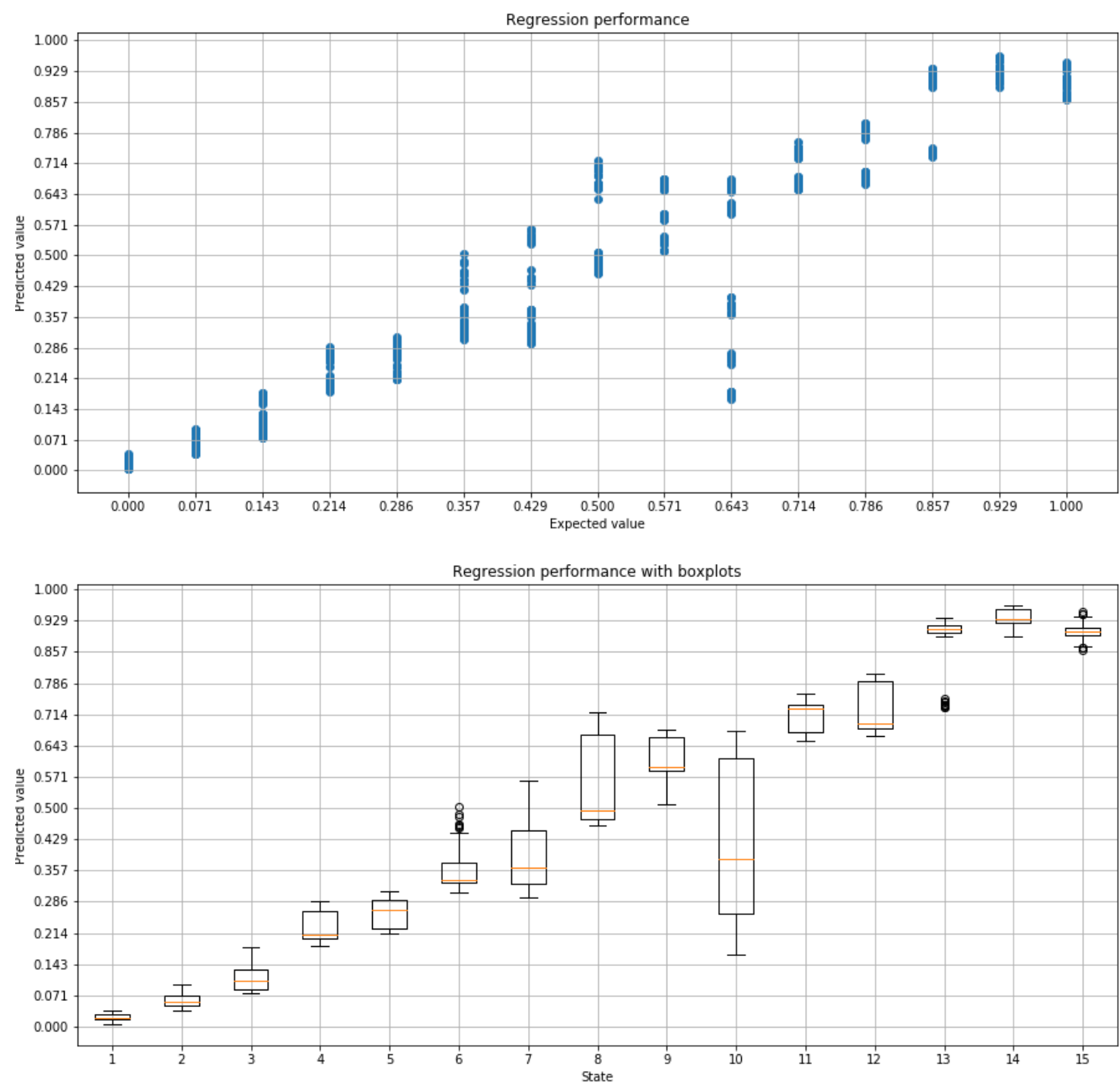

Source: Own

Fig. 9: Regression performance of the test set for the convolutional neural network

\subsection{Effects of Data Preparation}

The accuracy of the fully connected model is shown in Fig 10 with different configurations of data preparation; the results for the convolutional model are similar. Four different configurations were tested, each one with the addition of one extra data preparation step. Starting off without any data preparation, the accuracy of the network is equivalent as randomly guessing the state. With the addition of each of the data preparation measures the accuracy improves accordingly. It can be concluded that each of the data preparation measures explained in section 2.2 have a significant improvement on the performance of a particular model. 


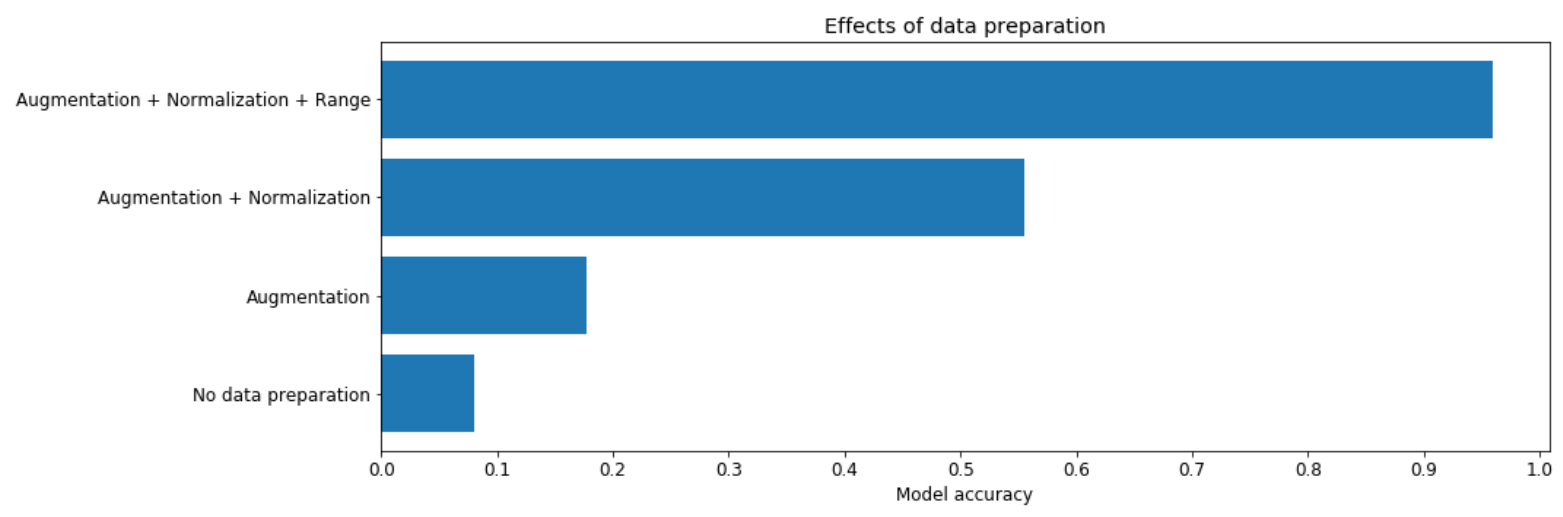

Source: Own

Fig. 10: Performance benefits gained by using data preparation

\section{$4 \quad$ Future Work}

As the classification spectral data is shown to have very high accuracy, there can be further experimentation with other fuel assembly states. For example, the network can be adapted to classify the exact tube where there is an anomaly by changing the testing setup to have sensors on each axis and to prepare the necessary states.

Further research into the generalization ability of the obtained networks is needed; they need to work in a real world environment where the container state will not exactly be one of the learned states.

Additional work is needed in the case of regression as it shows promise to be able to overcome the limitations with generalization. To accomplish this, the accuracy of the predicted values needs to be refined, possibly by tuning the network parameters or by constructing hybrid models of different regression solutions.

\section{Conclusion}

The trained neural networks achieve very high accuracy when classifying spectral data and do not show signs of overfitting.

When using the models to perform regression, the results are less promising. While it is possible to predict a value that is rather close to the expected result, the presence of numerous outliers is worrying. When fine tuning some of the parameters and combining the network with other analysis methods, it is possible that an estimate with sufficient accuracy can be achieved.

Convolutional neural networks are best suited for the analysis of spectral data as they can be built to greater complexity and can recognize local patterns in the data, which certainly is an advantage when considering spectral data. Even though time complexity is greater for the convolutional architectures, the time needed for training is still within reasonable bounds.

When applying different data preparation procedures, the performance of all networks increases accordingly. With the addition of each of the procedures, the overall accuracy of the networks sees a significant improvement.

\section{Acknowledgements}

The research was funded by the German Federal Ministry for Economic Affairs and Energy on the basis of a decision by the German Bundestag. Grant identification number: 1501518A/B. 


\section{Literature}

[1] FISS, D.; SCHMIDT, S.; REINICKE, S.; KRATZSCH, A.: Fundamental R\&D Work on Methods for State Monitoring of Transport and Storage Containers for Spent Fuel and Heat-Generating High-Level Radioactive Waste on Prolonged Intermediate Storage. In: $25^{\text {th }}$ International Conference on Nuclear Engineering. Paper No: ICONE25-67245, V009T15A039. ASME, 2017. ISBN 978-0-7918-5787-8. DOI: $\underline{10.1115 / \mathrm{ICONE} 25-67245}$

[2] BJERRUM, E. J.; GLAHDER, M.; SKOV, T.: Data Augmentation of Spectral Data for Convolutional Neural Network (CNN) Based Deep Chemometrics. In: ArXiv. [online]. 2017. Available from WWW: http://arxiv.org/abs/1710.01927

[3] CHOLLET, F. et al.: Keras. [online]. 2015. Available from WWW: https://keras.io

[4] ABADI M. et al.: TensorFlow: Large-Scale Machine Learning on Heterogeneous Distributed Systems. Preliminary White Paper. In: ArXiv Vanity. [online]. 2015. Available from WWW: https://www.arxiv-vanity.com/papers/1603.04467/ 


\section{VÝZKUM A VÝVOJ UMĚLÉ NEURONOVÉ SÍTĚ PRO SPEKTRÁLNÍ DATA}

Globální výzva k určení stavu obsahu přepravních a skladovacích kontejnerů pro vysoce radioaktivní odpady (sestavy vyhořelého paliva) nabízí jako jedno $\mathrm{z}$ možných řešení provedení vibračních analýz a vyhodnocení vibračních odezev pomocí umělých neuronových sítí. U tohoto př́stupu byla provedena první šetření. Data o vibracích jsou získána z testovacího nastavení, které modeluje sestavy palivového jaderného úložiště a je převedeno na frekvenční doménu pomocí Fourierovy transformace. Surová spektrální data jsou nejprve připravena normalizací rozšířením dat a omezením frekvenčního rozsahu. Tato opatření mají evidentně významný dopad na celkový výkon neuronových sítí. Za použití plně propojených a konvolučních neuronových sítí se na spektrálních datech provádí klasifikace a regrese. Ukázalo se, že klasifikace je možná s velmi vysokou přesností a regrese má velmi dobré výsledky s možnostmi zlepšení v pozdějších fázích. Konvoluční neuronové sítě se v obou př́ípadech jeví jako vynikající.

\section{UNTERSUCHUNG UND ENTWICKLUNG EINES KÜNSTLICHEN NEURALEN NETZES FÜR SPEKTRALE DATEN}

Die globale Herausforderung zur Bestimmung des Inhaltes von Transport- und Lagerungscontainern für hoch radioaktive Abfälle (Zusammenstellung von ausgebranntem Brennstoff) bietet als eine der möglichen Lösungen die Durchführung von Vibrationsanalysen und der Auswertung von Vibrationsrückmeldungen mit Hilfe künstlicher Neuronennetze. Bei diesem Ansatz wurden erste Untersuchungen durchgeführt. Die Daten über die Vibrationen wurden aus der Testeinstellung gewonnen, welche die Zusammenstellungen der Kernbrennstofflagerstätte modelliert und an einer Frequenzdomäne mit Hilfe der FourierTransformation durchgeführt wird. Die spektralen Rohdaten werden zunächst durch Normalisierung durch Erweiterung der Daten und durch Begrenzung des Frequenzbereichs vorbereitet. Diese Maßnahmen haben eine evident bedeutsame Auswirkung auf die Gesamtleistung der Neuronennetze. Bei der Verwendung voll verbundener und konvolutartiger Neuronennetze werden an den Spektraldaten eine Klassifikation und eine Regression durchgeführt. Es hat sich gezeigt, dass eine Klassifikation mit sehr hoher Genauigkeit möglich ist und die Regression sehr gute Ergebnisse mit Möglichkeiten der Verbesserung in späteren Phasen aufweist. Die konvolutartigen Neuronennetze erweisen sich in beiden Fällen als hervorragend.

\section{BADANIA I ROZWÓJ SZTUCZNEJ SIECI NEURONOWEJ DLA DANYCH WIDMOWYCH}

Wystosowano globalny apel do określenia stanu zapasu kontenerów transportowych i magazynowych na odpady wysoce radioaktywne (zestawy wypalonego paliwa). Jednym z możliwych rozwiązań jest wykonanie analiz wibracyjnych oraz ocena działania drgań przy pomocy sztucznych sieci neuronowych. Dla takiego podejścia wykonano pierwsze badania. Dane dotyczące drgań pozyskiwano $\mathrm{z}$ ustawienia testowego, które modeluje zestawy składowisk paliwa jądrowego i jest przetworzone na domenę częstotliwości przy pomocy transformacji Fouriera. Surowe dane widmowe są najpierw przygotowane w drodze normalizacji, powiększania zbiorów danych i ograniczenia zakresu drgań. Działania te mają jednoznacznie znaczący wpływ na ogólną wydajność sieci neuronowych. Przy wykorzystaniu w pełni połączonych i splotowych sieci neuronowych na podstawie danych widmowych dokonuje się klasyfikacji i regresji. Okazało się, że klasyfikacja możliwa jest z bardzo dużą dokładnością a regresja osiąga bardzo dobre wyniki z możliwością udoskonalenia na późniejszych etapach. Splotowe sieci neuronowe wydają się w obu przypadkach znakomite. 